\title{
Framework for urban freight transport analysis in medium-sized cities
}

\author{
Estrutura para análise do transporte urbano de carga em cidades médias
}

Mariana Flora[a], Henrique Ewbank[b] [D], José Geraldo Vidal Vieira[c] [D

[a] São Paulo University (USP), Production Engineering Department, São Paulo, SP, Brazil

[b] Facens University, Production Engineering Department, Sorocaba, SP, Brazil

[c] São Carlos Federal University (UFSCAR), Production Engineering Department, Sorocaba, SP, Brazil

How to cite: Flora, M., Ewbank, H., \& Vieira, J. G. V. (2019). Framework for urban freight transport analysis in medium-sized cities. urbe. Revista Brasileira de Gestão Urbana, v.11, e20180203. https://doi.org/10.1590/2175-3369.011.e20180203

\section{Abstract}

The urbanization process, especially the diverse aspects regarding size, function, position and growth of cities, significantly affect the Urban Freight Transport (UFT). This paper deals with behaviour of UFT in medium-sized cities. Here we will identify the attributes that characterize the Medium-sized Cities (MC), as well as the influence factors in UFT. In addition, a survey among specialists and public agents of mediumsized cities is presented, about the level of interaction between attributes that characterize MC and the factors that influence UFT. For analysis and validation of the opinion survey is performed non-parametric statistical test, and an analysis of the confidence interval to define the level of interaction between attributes and UFT factors. As a result, we provide a framework that demonstrates the interaction between attributes of MC and the factors that influence UFT. The factors "Projects and measures of local authorities", and "Infrastructure available to the UFT", together with the lack of studies related to freight transport (knowledge, innovation and technological advancement) were identified as the main issues that require attention on UFT in MC. This proposal may contribute to the decision makers regarding urban planning and brings a theoretical contribution to future research in UFT planning studies.

Keywords: Urban freight transport. Medium-sized cities. Brazilian medium-sized cities. Urbanization.

\section{Resumo}

O processo de urbanização, em especial os aspectos relacionados ao tamanho, função, posição e taxa de crescimento das cidades, afetam significativamente o transporte urbano de carga (TUC). Este artigo trata do comportamento do TUC em cidades médias. Aqui serão identificados os atributos que caracterizam e diferenciam as Cidades Médias (CM), e os fatores de influência no TUC. Para análise e validação da pesquisa de opinião foi realizado um teste estatístico não-paramétrico para comparação das distribuições das duas amostras - especialistas e agentes públicos, e uma análise do intervalo de confiança para definição do grau de interação entre os atributos e fatores. Como resultado, nós fornecemos uma estrutura que faz a interação entre

MF é mestranda em Engenharia de Produção, e-mail: marianaflora@gmail.com

HE é doutor em Administração, e-mail: henrique.vieira@facens.br

JGVV é doutor em Engenharia de Produção, e-mail: jose.vidal@ufscar.br 
os atributos do MC e os fatores que influenciam o TUC. Os fatores "Projetos e medidas de autoridades locais" $e$ "Infraestrutura disponível para o TUC", juntamente com a falta de subsídios (dados e pesquisas na área) para estudos relacionados ao transporte de cargas (conhecimento, inovação e avanço Tecnológico) foram identificados como os principais problemas que exigem atenção no TUC em MC. Esta proposta pode contribuir para os tomadores de decisão em relação ao planejamento urbano e traz uma contribuição teórica para pesquisas futuras em estudos de planejamento do TUC.

Palavras-chave: Transporte urbano de carga. Cidades médias. Cidades médias no Brasil. Urbanização.

\section{Introduction}

In the last 50 years, the world has undergone an intense process of urbanization that continues in an accelerated way (Bolay \& Rabinovich, 2004), especially in medium-sized cities, where this phenomenon has been occurring more vigorously when compared to large urban centers (Angeoletto et al., 2016; Bolay, 2016; Espindola et al., 2017; Gao et al., 2016).

In Brazil, approximately 36 million people live in cities considered medium-sized according to the classification of the Brazilian Institute of Geography and Statistics - IBGE (100 and 750 thousand inhabitants), equivalent to almost $20 \%$ of the Brazilian population (IBGE, 2016).

As the world continues to urbanize, the challenges to sustainable development will increasingly be concentrated in urban centers (Cohen, 2006). Medium-sized cities (MC) have become large urban centers in the near future, the challenges for sustainable development will be greater (UN, 2014; Cohen, 2006). It is noteworthy that MCs present the same problems of large cities, even on a smaller scale (Sathler et al., 2015; Ricieri et al., 2017). These problems refer to the environmental process of urbanization (Bolay, 2016; González et al., 2017), to inequality (Bolay, 2016), to disorderly growth (Bolay, 2016), and, above all, the sustainable development of urban freight transport (UFT) (Pojani \& Stead, 2015; Vasconcellos, 2005), especially in terms of ensuring accessibility to goods in expanding urban areas (Kin et al., 2017).

Oliveira et al. (2018a, p. 70) have attempted to establish an analytical framework considering urban logistics solutions by the number of population of the cities. For example, bays for parking and loading/unloading, pickup points and incentive for using non-motorized vehicles can be appropriate for all the size of the cities; cargo vehicle restrictions and low emission zone may be appropriate for medium-sized and large cities, and off-hours deliveries, urban distribution centers for large cities. However, urban logistics solutions should take into account also other attributes as following: the growth rate of urbanized areas or urban sprawl (Angeoletto et al., 2016); the position of cities in the urban hierarchy (Dias \& Araújo (2013) and urban function (Bolay \& Rabinovich, 2004). As far as the cities have become larger, these attributes require more complex urban logistics solutions (for instance, the implementation of a UDC, road pricing system).

Considering these challenges and the projections for the future ways of population arrangements and UFT issues, the medium-sized cities (MC) are taking a leading role in addressing the issues of sustainable urban development (Bolay \& Rabinovich, 2004; Bolay, 2016). Moreover, CM has greater potential for solving problems compared to larger urban centers (Pojani \& Stead, 2015, Schlesinger et al., 2015). In this sense, it is necessary to approach this question in the light of the urban context in which it is inserted (Lindholm \& Behrends, 2012).

Therefore, given the importance of urban freight transport (UFT) to consider the complexity and diversity of cities, as well as the prominent role of $\mathrm{MC}$ in this discussion, this work aims to identify the attributes that characterize the behavior of UFT in urban centers of medium size. Here we will analyze the relationship between the MC characterization attributes and the factors that influence the UFT, as well as the appreciation of the experts' and public agents' perceptions on the subject.

The main objective of the work is achieved through the following specific objectives:

- Define the attributes that characterize medium-sized cities;

- Evaluate the degree of interaction between attributes that characterize medium-sized cities and the factors that influence urban freight transport through literature review and opinion research with public experts and agents in order to prioritize UFT factors for MC;

- Define a UFT analysis framework for MC. 


\section{Urban freight transport and its influence factors}

As a starting point for defining the freight transport analysis framework in MC, it is necessary to obtain an overview of the influence factors in the UFT.

In order to understand how and why these factors influence the flow of goods in cities, they are presented here from their social, economic and environmental impacts, respectively, as follows (Allen et al., 2007; Lindholm \& Behrends, 2012; Portugal et al., 2011):

- Economic impact factors: they imply consumption of resources (time, money, space/land use and energy) and, consequently, impact on the efficiency of the delivery of goods and their access by the population.

- Environmental impact factors: they produce externalities related to the preservation of the environment, such as maintenance of air quality, soil quality (litter) and/or are related to climate change.

- Social impact factors: related to externalities that affect the quality of life of the population in cities, such as health (e.g. respiratory and hearing problems) and safety (traffic accidents and theft of cargo).

These factors are further classified into six macro blocks: 1) Projects and Measures adopted by Local Authorities; 2) Infrastructure for UFT; 3) Urban Space Configuration; 4) Companies Features, 5) Knowledge, Innovation and Technological Advancement, and 6) Population, as shown in Table 1.

Table 1 - Influence factors in urban freight transport

(To be continued)

\begin{tabular}{|c|c|c|c|c|}
\hline \multirow{2}{*}{ Factor } & \multirow[t]{2}{*}{ Study } & \multicolumn{3}{|c|}{ Impact } \\
\hline & & Economic & Environmental & Socia \\
\hline Political-cultural context & Lindholm \& Behrends (2012) & & & $X$ \\
\hline Degree of stakeholder involvement in the decision- & Kin et al. (2017) & & & $x$ \\
\hline making process & Holguín-Veras et al. (2017) & & & $x$ \\
\hline $\begin{array}{l}\text { Use of alternative fuels encouragement to } \\
\text { transportation companies }\end{array}$ & Kiba-Janiak (2017) & & $x$ & \\
\hline \multirow[t]{5}{*}{ UFT restriction measures } & Allen et al. (2007) & $x$ & & \\
\hline & Kiba-Janiak (2017) & $x$ & $x$ & \\
\hline & Lindholm \& Behrends (2012) & $x$ & & \\
\hline & Muñuzuri et al. (2005) & $x$ & & \\
\hline & Quak \& Koster (2009) & $x$ & $x$ & \\
\hline \multirow{2}{*}{$\begin{array}{l}\text { Level of inclusion of the UFT in the city's strategic } \\
\text { planning }\end{array}$} & Kiba-Janiak (2017) & $x$ & & \\
\hline & Lindholm \& Behrends (2012) & $x$ & & \\
\hline \multirow[t]{2}{*}{ Public-Private Partnerships } & Allen et al. (2007) & $x$ & & \\
\hline & Kin et al. (2017) & $x$ & & \\
\hline \multirow{2}{*}{$\begin{array}{c}\text { Policies with an appropriate focus on the drivers of } \\
\text { externalities }\end{array}$} & Quak \& Koster (2009) & & $x$ & \\
\hline & Vasconcellos (2005) & & $x$ & \\
\hline \multirow{2}{*}{$\begin{array}{c}\text { Policies that change the logistics flow in equilibrium to } \\
\text { the inefficiency of available infrastructure }\end{array}$} & Allen et al. (2007) & $x$ & & \\
\hline & Muñuzuri et al. (2005) & $x$ & & \\
\hline \multicolumn{5}{|l|}{ Safety } \\
\hline \multirow[t]{2}{*}{ Infrastructure for loading and unloading of goods } & Alho et al. (2018) & $x$ & & \\
\hline & Muñuzuri et al. (2005) & $x$ & & \\
\hline \multirow[t]{2}{*}{ Infrastructure for intermodal transport } & Muñuzuri et al. (2005) & $x$ & & $x$ \\
\hline & Portugal et al. (2011) & $x$ & & $x$ \\
\hline \multirow[t]{2}{*}{ Public facilities and terminals for the UFT } & Kiba-Janiak (2017) & $x$ & & \\
\hline & Muñuzuri et al. (2005) & $x$ & & \\
\hline \multirow[t]{4}{*}{ Circulation routes to the UFT } & Allen et al. (2012) & $x$ & & \\
\hline & Allen et al. (2007) & $x$ & & $x$ \\
\hline & Lindholm \& Behrends (2012) & $x$ & & \\
\hline & Portugal et al. (2011) & & & $x$ \\
\hline \multirow{4}{*}{$\begin{array}{c}\text { Access to infrastructure and transport service } \\
\text { Allocation of spaces for the logistical operations of } \\
\text { cities }\end{array}$} & Kiba-Janiak (2017) & $x$ & & \\
\hline & Allen et al. (2012) & $x$ & & \\
\hline & Allen et al. (2007) & $x$ & & \\
\hline & Muñuzuri et al. (2005) & $x$ & & \\
\hline \multirow{3}{*}{$\begin{array}{l}\text { Places of concentration of jobs } \\
\text { Location and extension of facilities and commercial } \\
\text { businesses }\end{array}$} & Boarnet et al. (2017) & $x$ & & \\
\hline & Allen et al. (2012) & $x$ & & \\
\hline & Lindholm \& Behrends (2012) & $x$ & & \\
\hline
\end{tabular}




\begin{tabular}{|c|c|c|c|c|}
\hline Size of urbanized areas & Allen et al. (2012) & $x$ & & COTा \\
\hline $\begin{array}{c}\text { Specific characteristics of the customer/receiver } \\
\text { Type of business segment }\end{array}$ & Allen et al. (2007) & $x$ & & \\
\hline Data availability & $\begin{array}{l}\text { Portugal et al. (2011) } \\
\text { Rødseth (2017) }\end{array}$ & $\begin{array}{l}X \\
X\end{array}$ & & \\
\hline Ideas that promote green UFT & Kiba-Janiak (2017) & & $x$ & \\
\hline Research on UFT & Lindholm \& Behrends (2012) & & $X$ & \\
\hline Logistics planning and best practices on UFT & Alho et al. (2018) & $x$ & & \\
\hline & Allen et al. (2007) & $x$ & & \\
\hline & Rødseth (2017) & $x$ & & \\
\hline Applied Technologies in UFT & Allen et al. (2007) & $x$ & & \\
\hline & Muñuzuri et al. (2005) & $x$ & & \\
\hline & Swiatek et al. (2014) & $x$ & & \\
\hline Consumer behavior & Allen et al. (2007) & $x$ & & \\
\hline & Guldbrand et al. (2015) & $x$ & & \\
\hline $\begin{array}{c}\text { Conduct of the population towards policies and } \\
\text { measures directed to the UFT }\end{array}$ & Holguín-Veras et al. (2017) & & & $x$ \\
\hline Population size & Kin et al. (2017) & $x$ & & \\
\hline
\end{tabular}

Source: Own elaboration (2018)

\section{Medium-sized cities}

After identifying the main factors influencing the flow of goods in cities, the next step is to investigate how these factors impact in medium-sized urban centers. In order to accomplish it, it is necessary to establish what would be the definition of Medium-sized Cities.

Studies regarding UFT in Brazilian cities indicate that there is no problem and solution common to all cities (Oliveira et al., 2018b). Therefore, it is necessary to investigate the reality of each city so that it is possible to arrive at solutions that minimize the externalities of the urban transport of loads (Oliveira et al., 2018a). It is important taking into account the demographic and economic parameters of cities, as well as their role in the regional hierarchy.

Although there are studies that bring the characterization of urban transport loads under different approaches, we do not yet see many studies that consider the different realities and scales of urban concentration (Kin \& Macharis, 2017; Pojani \& Stead, 2015). Perhaps because, in the case of medium-sized cities, there are different definitions for this type of urban agglomeration (Bolay, 2016, Conte \& Fresca, 2011, França \& Soares, 2014, Sathler \& Amorim Filho, Varajão, 2015) and to classify urban logistics solutions according to size of the city it is still a challenge. Although Oliveira et al. (2018a) have pointed out this proposal, to consider only the number of population to implement those urban logistics solutions is at minimal limited. That said, it is necessary first to establish what the definition of Medium Cities would be.

From national and international references, MC can be characterized according to four main attributes: 1) population size; 2) growth rate of urbanized areas or urban sprawl; 3) position of cities in the urban hierarchy; and 4) urban function of cities. Table 2 provides a summary of the studies examined.

Table 2 - Attributes of characterization of medium-sized cities

(To be continued)

\begin{tabular}{ccc}
\hline Attribute for characterization & Attribute behavior in medium-sized cities & Studies \\
\hline Population size & $\begin{array}{c}\text { Cities with population between 1 and } 5 \text { million inhabitants. } \\
\text { Cities and/or population arrangements (grouping of two or more } \\
\text { municipalities where there is a strong population integration by } \\
\text { commuting) with population between } 100 \text { and } 750 \text { thousand } \\
\text { inhabitants. }\end{array}$ & $\begin{array}{c}\text { Salas-Olmedo \& Nogués (2012); } \\
\text { IBGE (2016) }\end{array}$ \\
$\begin{array}{c}\text { Cities with population between } 14 \text { and } 400 \text { thousand inhabitants. } \\
\text { Growth rate of urbanized } \\
\text { areas or urban sprawl }\end{array}$ & $\begin{array}{c}\text { In general, MCs present a more accelerated process of urban } \\
\text { expansion }\end{array}$ & $\begin{array}{c}\text { Angeoletto et al. (2016); Bolay } \\
\text { (2016); Espindola et al. (2017); } \\
\text { Gao et al. (2016) }\end{array}$ \\
\hline
\end{tabular}




\begin{tabular}{|c|c|c|}
\hline \multirow[t]{2}{*}{$\begin{array}{l}\text { Position of cities in the urban } \\
\text { hierarchy }\end{array}$} & $\begin{array}{l}\text { The MCs, given their function of intermediation in the hierarchy of } \\
\text { cities, occupy a position of strategic nucleus in the urban networks. }\end{array}$ & $\begin{array}{l}\text { Amorim Filho et al. (2007); Conte } \\
\text { \& Fresca (201 1); Dias \& Araújo } \\
\text { (2013); Santos (2009) }\end{array}$ \\
\hline & $\begin{array}{c}\text { MCs present } 4 \text { levels of urban hierarchy: 1) Large Regional } \\
\text { Centers, 2) Medium-sized upper-level cities, 3) Medium-sized Cities, } \\
\text { and 4) Emerging Urban Centers. }\end{array}$ & Amorim Filho et al. (2007) \\
\hline \multirow[t]{2}{*}{ Urban Function } & $\begin{array}{c}\text { MCs in general have relevant importance in the global economic } \\
\text { system. }\end{array}$ & $\begin{array}{l}\text { Bolay \& Rabinovich (2004); Conte } \\
\text { \& Fresca (2011) }\end{array}$ \\
\hline & $\begin{array}{l}\text { MCs generally present } 11 \text { types of urban function that } \\
\text { characterize their role in the global economic system (see Table 4) }\end{array}$ & Bolay \& Rabinovich (2004) \\
\hline
\end{tabular}

Source: Own elaboration (2018).

Based on the studies that describe the different behaviors of such attributes, a characterization model was established to demonstrate if indeed an urban center can be denominated as a Medium-sized City. The model, presented in Table 3, determines how each attribute is presented in medium-sized cities.

Table 3 - Feature model for medium-sized cities

\begin{tabular}{|c|c|c|c|c|}
\hline & \multicolumn{4}{|c|}{ Attributes that characterize as medium-sized cities } \\
\hline & $\begin{array}{l}\text { Growth rate of } \\
\text { urbanized areas } \\
\text { or urban sprawl }\end{array}$ & Population size & $\begin{array}{l}\text { Position of cities in the } \\
\text { urban hierarchy }\end{array}$ & $\begin{array}{l}\text { Urban Function } \\
\text { Typology for Medium-sized Cities }\end{array}$ \\
\hline $\begin{array}{l}\text { Large } \\
\text { Cities }\end{array}$ & Accelerated & above 750k inhabitants & $\begin{array}{l}\text { Metropolis and/or } \\
\text { Major Urban Centers }\end{array}$ & NA \\
\hline $\begin{array}{l}\text { Medium } \\
\text { Cities }\end{array}$ & Very accelerated & $\begin{array}{l}\text { between } 200 \mathrm{k} \text { and } \\
750 \mathrm{k} \text { inhabitants } \\
\text { (average point in } 400 \mathrm{k} \\
\text { ponto médio em } \\
\text { 400k inhabitants) }\end{array}$ & $\begin{array}{c}\text { Major Regional } \\
\text { Centers }\end{array}$ & $\begin{array}{l}\text { Regional market; Service center; Economic } \\
\text { locality; Tourist center; Communication hub; } \\
\text { Metropolitan suburbs; National/International } \\
\text { Interface; Cities in conurbation area; } \\
\text { Association of a group of cities; Urban region }\end{array}$ \\
\hline & & $\begin{array}{l}\text { between } 70 \mathrm{k} \text { and } \\
\text { 200k inhabitants } \\
\text { between 14ke } \\
\text { 100k inhabitants }\end{array}$ & $\begin{array}{l}\text { Higher-level MC } \\
\text { Medium-sized cities }\end{array}$ & $\begin{array}{c}\text { Regional market; Tourist center; Communication } \\
\text { hub; National/International Interface; Cities in } \\
\text { conurbation area; Association of a group of } \\
\text { cities; Urban region }\end{array}$ \\
\hline & & up to $50 \mathrm{k}$ inhabitants & $\begin{array}{l}\text { Emerging Urban } \\
\text { Centers }\end{array}$ & $\begin{array}{c}\text { Tourist center; National/International Interface; } \\
\text { Cities in conurbation area; Association of a } \\
\text { group of cities; Urban region }\end{array}$ \\
\hline $\begin{array}{l}\text { Small } \\
\text { Cities }\end{array}$ & Very accelerated & up to 14,000 inhabitants & Small Cities & NA \\
\hline
\end{tabular}

Source: Own elaboration (2018).

\section{Medium-sized cities and urban freight transportation}

In this section, we present the main questions about Urban Cargo Transportation in Medium Cities, considering the classification established in Table 1.

With regard to "Projects and Measures adopted by Local Authorities", four main issues are highlighted in the context of Medium-sized Cities: 1) the UFT Restriction Measures; 2) the level of inclusion of the UFT in the city's strategic planning; 3 ) the degree of involvement of the stakeholders in the decision-making process; and 4) adoption of policies with an appropriate focus on the drivers of externalities (González et al., 2017; Kramar et al., 2015; Pojani \& Stead, 2015; Van Lier et al., 2016).

Regarding "UFT Restriction Measures", which aim to improve the livability of the population with freighters in urban centers, time windows for delivery and collection of goods have been quite restrictive in medium-sized cities (Van Lier et al., 2016). In contrast, low-cost measures such as speed restriction and reasonable parking fees appeared as acceptable and feasible interventions to local MC governments (Pojani \& Stead, 2015).

Regarding the "Level of Inclusion of UFT in the Strategic Planning of the City", this issue is not yet sufficiently applied in practice, although their strong impact on the quality of life of the population is recognized by local governments (Kramar et al., 2015). Even in cases where urban logistics are considered in the strategic plan, the strategies adopted has not always proved to be adequate to the reality of MC, since 
such adoption has usually been implemented in large cities (Pojani \& Stead, 2015). In addition, the local governments of these cities should adopt joint strategies, not only isolated measures (Pojani \& Stead, 2015). Regarding this point, there is still a need to define a clear methodology in the definition of city plans (Van Lier et al., 2016).

In relation to the question of the "Degree of stakeholder involvement in the decision-making process", the need for greater stakeholder involvement (Pojani \& Stead, 2015; Van Lier et al., 2016) is verified in the MCs. This question directly reflects the divergence regarding the practices adopted by local authorities in MC, especially regarding the positioning of Retailers (Van Lier et al., 2016). A greater involvement would bring less divergence among those involved (Van Lier et al., 2016), as well as awareness raising and education campaigns related to the theme (Pojani \& Stead, 2015).

A final aspect concerning the measures taken by local authorities refers to the issue of "Adopting policies with a proper focus on the drivers of externalities". Considering that in MCs, the highest pollution factor comes from the vehicular activity (González et al., 2017), it is important that local governments pay special attention to this aspect.

The "Infrastructure for UFT" is insufficient to urban logistics in Medium Cities. The spaces defined for loading and unloading below the required demand, as well as problematic traffic (congestion), point to the need for more adequate infrastructure (Van Lier et al., 2016). Paying more attention to the maintenance of the current road infrastructure than the expansion or construction of new structures would already bring significant results to the UFT in these cities (Pojani \& Stead, 2015).

As for the "Urban Space Configuration", the accelerated process of urban sprawl in the MC is highlighted, and the consequent increase in traffic and air pollution (Espindola et al., 2017). In this aspect, reducing the speed of expansion of the urbanized areas in the MC is not sufficient to obtain positive impacts to the UFT, it is also necessary that the urbanization process takes place in a planned and organized manner (Pojani \& Stead, 2015).

Regarding the "Knowledge, Innovation and Technological Advancement" related to UFT in Medium-sized Cities, it is highlighted the lack of data and benchmarking that support applied studies to urban logistics, becoming unfeasible the use of performance analysis tools (Karagiannakidis et al., 2014). In this context, the use of low-cost mobile technologies is a feasible alternative for UFT users in medium-sized cities (Pojani \& Stead, 2015). In addition to this type of resource, environments with GIS technology have also shown to be useful in assisting MC decision makers (Gutiérrez-Gallego et al., 2015). In a consolidated manner, the main questions about UFT in MC, regarding the literature review survey, are presented in Table 4.

Table 4 - Main issues about UFT in MC

\begin{tabular}{|c|c|c|c|c|}
\hline \multicolumn{2}{|c|}{ UFT influence factors } & Questions about UFT in MC & Possible solutions & Studies \\
\hline \multirow{5}{*}{$\begin{array}{l}\text { Projects and } \\
\text { Measures } \\
\text { adopted by } \\
\text { Local Authorities }\end{array}$} & UFT restriction measures & $\begin{array}{l}\text { Time windows for delivery/pick-up } \\
\text { have been quite restrictive }\end{array}$ & $\begin{array}{c}\text { Consider adopting less } \\
\text { costly and less restrictive } \\
\text { measures }\end{array}$ & $\begin{array}{l}\text { Pojani \& Stead } \\
\text { (2015); Van Lier et } \\
\text { al. (2016) }\end{array}$ \\
\hline & $\begin{array}{l}\text { Level of inclusion of UFT } \\
\text { in the strategic planning } \\
\text { of cities }\end{array}$ & $\begin{array}{c}\text { It is not sufficiently used in practice, } \\
\text { although its importance is } \\
\text { recognized by local governments } \\
\text { The strategies adopted do not } \\
\text { always prove adequate to the } \\
\text { reality of CM }\end{array}$ & $\begin{array}{l}\text { Inclusion of UFT in strategic } \\
\text { plans in more MC, and its } \\
\text { practical application } \\
\text { Adoption of joint strategies } \\
\text { and not just isolated } \\
\text { measures }\end{array}$ & $\begin{array}{l}\text { Kramar et al. (2015); } \\
\text { Pojani \& Stead } \\
\text { (2015) }\end{array}$ \\
\hline & \multirow{2}{*}{$\begin{array}{l}\text { Degree of stakeholder } \\
\text { involvement in the } \\
\text { decision-making } \\
\text { process }\end{array}$} & $\begin{array}{l}\text { Need for greater involvement of } \\
\text { stakeholders }\end{array}$ & $\begin{array}{l}\text { Greater involvement would } \\
\text { bring less divergence } \\
\text { among those involved }\end{array}$ & \multirow{2}{*}{$\begin{array}{c}\text { Pojani \& Stead } \\
\text { (2015); Van Lier et } \\
\text { al. (2016) }\end{array}$} \\
\hline & & $\begin{array}{l}\text { Divergence between stakeholders } \\
\text { regarding practices adopted by } \\
\text { local authorities }\end{array}$ & $\begin{array}{l}\text { Awareness and education } \\
\text { campaigns on the subject }\end{array}$ & \\
\hline & $\begin{array}{l}\text { Policies focused on the } \\
\text { drivers of externalities }\end{array}$ & $\begin{array}{l}\text { In MCs, the greatest pollution factor } \\
\text { comes from vehicular activity }\end{array}$ & $\begin{array}{c}\text { Adoption of more effective } \\
\text { measures against pollution } \\
\text { causes }\end{array}$ & $\begin{array}{l}\text { González et al. } \\
\text { (2017) }\end{array}$ \\
\hline \multicolumn{2}{|c|}{ Infrastructure availability for UFT } & $\begin{array}{l}\text { Clearance spaces for loading and } \\
\text { unloading below required demand } \\
\text { Problem traffic (congestion) }\end{array}$ & $\begin{array}{c}\text { Prioritize maintenance of } \\
\text { existing roads than building } \\
\text { new ones } \\
\text { It is necessary that the }\end{array}$ & $\begin{array}{l}\text { Pojani \& Stead } \\
\text { (2015); Van Lier et } \\
\text { al. (2016) }\end{array}$ \\
\hline \multicolumn{2}{|c|}{ Urban Space Configuration } & $\begin{array}{l}\text { Urban sprawl in MC occurs in an } \\
\text { accelerated manner }\end{array}$ & $\begin{array}{c}\text { urbanization process takes } \\
\text { place in a planned and } \\
\text { organized way }\end{array}$ & $\begin{array}{l}\text { Espindola et al. } \\
\qquad(2017)\end{array}$ \\
\hline
\end{tabular}




\begin{tabular}{|c|c|c|c|}
\hline $\begin{array}{l}\text { Knowledge, Innovation and Technological } \\
\text { Advancement }\end{array}$ & $\begin{array}{l}\text { Lack of data and benchmarking } \\
\text { based on studies of urban logistics }\end{array}$ & $\begin{array}{c}\text { Use of already available } \\
\text { and inexpensive mobile } \\
\text { technologies } \\
\text { Use of GIS technology to aid } \\
\text { decision making }\end{array}$ & $\begin{array}{l}\text { Gutiérrez-Gallego } \\
\text { et al. (2015); } \\
\text { Karagiannakidis et } \\
\text { al. (2014); Pojani \& } \\
\text { Stead (2015) }\end{array}$ \\
\hline
\end{tabular}

Source: Own elaboration (2018)

\section{Method}

In addition to the concepts presented so far, a survey was conducted with 10 specialists (researchers) in UFT and 20 public agents of Brazilian MCs to evaluate the level of interaction between the attributes that differentiate the Medium Cities versus the factors that influence the UFT. The cities of the respective public agents are listed in Table 5 and were selected according to the criteria presented in Table 3.

Table 5 - Brazilian medium-sized cities surveyed

\begin{tabular}{cccc}
\hline City & State & Region & Population \\
\hline Caldas Novas & GO & Midwest & 70,473 \\
Acaraú & CE & Northeast & 57,542 \\
Bacabal & MA & Northeast & 77,860 \\
Ipojuca & NE & Northeast & 91,341 \\
Cascavel & CE & Northeast & 296,537 \\
Caraguatatuba & SP & Southeast & 55,414 \\
Itu & SP & Southeast & 67,875 \\
Januária & MG & Southeast & 67,875 \\
Cataguases & MG & Southeast & 74,171 \\
Alfenas & MG & Southeast & 77,618 \\
Caçapava & SP & Southeast & 91,162 \\
Aracruz & SS & Southeast & 93,325 \\
Poços de Caldas & Southeast & 151,449 \\
Pindamonhangaba & SP & Southeast & 164,000 \\
Sete Lagoas & MG & Southeast & 229,485 \\
Franca & SP & Southeast & 360,544 \\
Juiz de Fora & SG & Southeast & 538,764 \\
São José do Rio Preto & SP & Southeast & 549,203 \\
Castro & PR & South & 67,082 \\
Alegrete & RS & South & 78,984 \\
\hline & Source: Own elaboration, based on lBGE (2016) & \\
\hline
\end{tabular}

The survey allows inferring how the characteristics attributed to the Medium-sized Cities can affect the influence factors related to the Urban Freight Transport. On a scale of 0 to 10, respondents were asked about the degree of relationship between every factor versus every attribute, for a total of 24 variables.

Prior to the calculation to define the degree of interaction, the Kruskal-Wallis (KW) technique verified whether or not there was a difference between the groups of respondents - Public Agents and Specialists. Since the data did not meet the assumptions of parametric tests, especially the normally distributed data, KW test presented as more suitable for testing differences about two datasets.

The analysis of variance of a Kruskal-Wallis factor consists of a non-parametric method used to decide if $\mathrm{k}$ independent samples come from different populations. The technique in this case is presented as appropriate, since it tests the null hypothesis that the kamples come from the same population or from identical populations with the same median (Siegel \& Castellan Jr, 2006). If the k samples are indeed drawn from the same population or from identical populations, that is, if the null hypothesis is true, then the sample distribution of the Kruskal-Wallis statistic can be calculated.

After checking the samples, the means were calculated for each of the variables, as well as their confidence interval. The calculation of the confidence interval in addition to the mean becomes necessary, since a point estimate does not inform how close the measure is to the actual measurement. In other words, limits 
representing a range of plausible values for a parameter are a good way to arrive at a more accurate estimate (Montgomery, 2012).

The KW calculation for the 24 variables, at a significance level of 5\%, showed that for all of them there was no difference between Public Agents and Specialists groups. These results suggest that Public Agents cargo are already filled by Specialists. Thus, both groups were treated as a single sample, and the next step was to define the interaction levels between the UFT factors and the characteristics of the Medium-sized Cities. This analysis was based on the averages of the scores attributed by the respondents. Table 6 shows the $95 \%$ confidence interval for the scores assigned by the respondents, for each variable.

Table 6 - Confidence interval of the degrees of interaction between MC attributes and UFT influence factors

\begin{tabular}{|c|c|c|c|c|c|}
\hline \multicolumn{6}{|c|}{ Attributes for Characterization of Medium-sized Cities } \\
\hline & & Population size & $\begin{array}{l}\text { Size of urbanized areas } \\
\text { or urban sprawl }\end{array}$ & $\begin{array}{l}\text { Position of cities in the } \\
\text { urban hierarchy }\end{array}$ & Urban Function \\
\hline \multirow{18}{*}{ 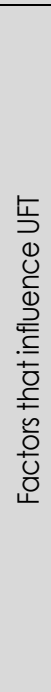 } & Projects and & Variable 1 & Variable 7 & Variable 13 & Variable 19 \\
\hline & Measures adopted & Average $\geq 6,941$ & Average $\geq 6,694$ & Average $\geq 6,375$ & Average $\geq 7,322$ \\
\hline & by Local Authorities & Average $\leq 8,126$ & Average $\leq 8,372$ & Average $\leq 8,158$ & Average $\leq 8,678$ \\
\hline & Infrastructure & Variable 2 & Variable 8 & Variable 14 & Variable 20 \\
\hline & $\begin{array}{l}\text { Intrastructure } \\
\text { available for } 1\end{array}$ & Average $\geq 6,440$ & Average $\geq 6,541$ & Average $\geq 6,197$ & Average $\geq 7,030$ \\
\hline & & Average $\leq 7,960$ & Average $\leq 8,059$ & Average $\leq 8,003$ & Average $\leq 8,637$ \\
\hline & & Variable 3 & Variable 9 & Variable 15 & Variable 21 \\
\hline & Urban space & Average $\geq 6,720$ & Average $\geq 6,304$ & Average $\geq 6,786$ & Average $\geq 6,504$ \\
\hline & Contiguration & Average $\leq 8,147$ & Average $\leq 7,830$ & Average $\leq 8,214$ & Average $\leq 8,030$ \\
\hline & Comnanies & Variable 4 & Variable 10 & Variable 16 & Variable 22 \\
\hline & Companies & Average $\geq 5,525$ & Average $\geq 5,140$ & Average $\geq 6,285$ & Average $\geq 6,171$ \\
\hline & reatures & Average $\leq 7,275$ & Average $\leq 7,0600$ & Average $\leq 8,049$ & Average $\leq 7,963$ \\
\hline & Knowledge, & Variable 5 & Variable 11 & Variable 17 & Variable 23 \\
\hline & Innovation and & Average $\geq 5,519$ & Average $\geq 4,917$ & Average $\geq 6,154$ & Average $\geq 6,037$ \\
\hline & $\begin{array}{l}\text { lechnological } \\
\text { Advancement }\end{array}$ & Average $\leq 7,415$ & Average $\leq 6,750$ & Average $\leq 7,846$ & Average $\leq 7,763$ \\
\hline & & Variable 6 & Variable 12 & Variable 18 & Variable 24 \\
\hline & Population & Average $\geq 6,423$ & Average $\geq 6.379$ & Average $\geq 6,195$ & Average $\geq 6,495$ \\
\hline & & Average $\leq 7,977$ & Average $\leq 8,021$ & Average $\leq 7,739$ & Average $\leq 7,971$ \\
\hline
\end{tabular}

Source: Own elaboration (2018).

\section{Results and discussion}

From the confidence interval of the degree of relationship between the factors that influence the transport of cargo and the attributes that characterize the Medium-sized Cities, a framework is proposed that describes this relation, as presented in Table 7. The framework for analysis of the interaction between MC attributes and the UFT influence factors, describes the relationship between medium-sized cities and cargo transportation.

Table 7 - Framework for analysis of the interaction between MC attributes and UFT influence factors

\begin{tabular}{|c|c|c|c|c|c|}
\hline \multicolumn{6}{|c|}{ Attributes for Characterization of Medium-sized Cities } \\
\hline & & Population size & $\begin{array}{c}\text { Size of urbanized areas or } \\
\text { urban sprawl }\end{array}$ & $\begin{array}{c}\text { Position of cities in the urban } \\
\text { hierarchy }\end{array}$ & Urban Function \\
\hline \multirow{6}{*}{ 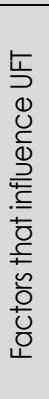 } & $\begin{array}{c}\text { Projects and Measures } \\
\text { adopted by Local } \\
\text { Authorities }\end{array}$ & High & High & High & Very High \\
\hline & $\begin{array}{c}\text { Infrastructure available for } \\
\text { UFT }\end{array}$ & High & High & High & High \\
\hline & Urban Space Configuration & High & High & High & High \\
\hline & Companies Features & Medium & Medium & High & High \\
\hline & $\begin{array}{c}\text { Knowledge, Innovation and } \\
\text { Technological } \\
\text { Advancement }\end{array}$ & Medium & Medium & High & Medium \\
\hline & Population (Behavior) & High & High & High & High \\
\hline
\end{tabular}




\begin{tabular}{c} 
Average equal to 0 - NO interaction \\
Average from 0 up to 4 - degree of interaction LOW \\
Average from 4 up to 7 - degree of interaction MEDIUM \\
Average from 7 up to 8 - degree of interaction HIGH \\
Average from 8 or higher - degree of interaction VERY HIGH \\
\hline
\end{tabular}

Source: Own elaboration (2018).

The framework presented in Table 7 did not have zero-degree variables or low interaction degree variables between MC Attributes and UFT Influence Factors. It means that, size, size of urbanized areas or sprawl logistics/growth of the cities, position of cities in the urban hierarchy and function of cities in urbanization are attributes at minimal important to be addressed in UFT regarding the UFT factors analyzed.

Among the 24 defined variables, 1 presented a "Very High" grade (i.e. at least $80 \%$ of degree of certainty), 18 variables presented "High" grade (i.e. at least $70 \%$ of degree of certainty) and 5 variables presented "Medium" degree (i.e. at least $40 \%$ of degree of certainty) of interaction.

Considering UFT influence factors, the "Projects and Measures adopted by Local Authorities" factor presented the highest degree of interaction with the Attributes for Characterization of Medium-sized Cities, especially with the attribute "Urban Function", which characterizes the economic vocation of the city. This interaction means $80 \%$ of degree of certainty or above it to represent how a urban function is important to establish projects and measures by the local authorities. This result corroborates with Van Lier et al. (2016) and Pojani \& Stead (2015), indicating that time windows for goods delivery, and speed and parking restrictions are acceptable and feasible urban functions for middle-sized city governments.

The factors "Infrastructure available for UFT" and "Urban Space Configuration" presented a high degree of interaction (or between $70 \%$ or $80 \%$ of degree of certainty) with all attributes, according to the Public Agents and Specialists. In particular, with regard to "Infrastructure available for UFT", the result found recognized the high importance given to this factor by local governments (Kramar et al., 2015), as well as by the transport specialists. It was verified that the factor "Urban Space Configuration" had a high interaction level with urban sprawl (Espindola et al., 2017), and, as stated by Pojani \& Stead (2015), has an urban function in the sense of urban planning for the growth of the city. Besides these, other attributes were identified as relevant, such as the size of the population and the position of the city in the urban hierarchy, whether acting as a major regional center, as a higher-level MC, as MC itself or as an emerging urban center (Amorim Filho et al., 2007).

It is noteworthy that the "Companies Features" factor presented medium-degree interaction with attributes of a demographic nature - "Population Size" and "Size of Urbanized Areas" - and a high degree with the attributes "Position in the urban hierarchy" and "Urban Function".

The "Knowledge, Innovation and Technological Advancement" factor has a high degree of interaction with the attribute "Position of cities in the urban hierarchy", and medium degree of interaction with the others. This indicates the importance that the technological advance represents in the evolution of the cities within the hierarchy of the MC. This advance can be identified through the adoption of mobile technologies already available (Pojani \& Stead, 2015) and the use of geographic information systems (GIS) (Gutiérrez-Gallego et al., 2015). However, this interaction is still quite low. It means that at $40 \%$ of degree of certainty that population size and urban sprawl do not affect the company features and knowledge, innovation and technological advancement in UFT planning.

The influence factor "Population", which refers to the behavior and conduct of the population, presented a high degree of interaction with all attributes of characterization of the Medium-sized Cities. In other words, education and population awareness, which are factors that directly affect the UFT, can be represented by the size of the population, urban sprawl, the position of the city in the hierarchy and its urban function.

\section{Conclusions}

The literature review places medium-sized cities as a potential laboratory for studies aiming to improve the flow of goods in urban centers. As MC have the same problems of the great urban centers, the mid-size arrangements present more opportunities for reversal of the problems compared to the large cities. 
The framework for analysis of the interaction between MC attributes and UFT influence factors presented that there is no interaction at low levels with none of the MC characterization attributes. Those results reinforce the idea that the feature of cities, in the whole, is an important variable in the analyses involving urban freight transport.

The factors "Projects and Measures of Local Authorities", and "Infrastructure available to the UFT", together with the lack of subsidies (data and research in the area) for studies related to freight transport (Knowledge, Innovation and Technological Advancement) were identified as the main issues that require attention on UFT in MC. In other words, if a policymaker has an intention to improve any infrastructure available for UFT in MC, for example, these characteristics of the cities should be taking into account in the urban planning. Moreover, this framework may be guidance for any urban logistics solution.

It is noteworthy that the factor "Knowledge, Innovation and Technological Advancement" was the item that received the lowest marks according to the assessment of specialists and public agents, which shows the lack of studies that deepen the theme of freight transportation in cities due to the size of urban centers.

This framework serves as a starting point for future studies and research in urban cargo transportation planning, as well as can help decision makers in their actions and policies regarding the flow of goods in these urban centers.

\section{Referências}

ALHO, A. R., ABREU E SILVA, J., SOUSA, J., BLANCO, E. (2018). Improving mobility by optimizing the number, location and usage of loading/unloading bays for urban freight vehicles. Transportation Research Part D: Transport and Environment, 61, 3-18.

ALLEN, J., THORNE, G., BROWNE, M. (2007). Good Practice Guide on Urban Freight Transport. BESTUFS.

ALLEN, J., BROWNE, M., CHERRETT, T. (2012). Investigating relationships between road freight transport, facility location, logistics management and urban form. Journal of Transport Geography, 24, 45.

AMORIM FILHO, O., RIGOTTI, J., CAMPOS, J. (2007). Os Níveis Hierárquicos das Cidades Médias de Minas Gerais. Raega Curitiba, 13, 7-18.

ANGEOLETTO, F., CORREA SANTOS, J. W., RUIZ SANZ, J. P., FREDERICO FONSECA DA SILVA, F., ALBERTÍN, R. (2016). Socio-environmental typology of Brazilian medium size cities: contributions for a sustainable urban development. Brazilian Journal of Urban Management, 8(2), 272-287.

BOLAY, J. C., RABINOVICH, A. (2004). Intermediate cities in Latin America - risk and opportunities of coherent urban development. Cities, 21, 407-421.

BOLAY, J. C. (2016). Prosperity and Social Inequalities: Montes Claros, How to Plan an Intermediary City in Brazil. Current Urban Studies, 4, 175-174.

BOARNET, M.; HONG, A.; SANTIAGO-BARTOLOMEI, R. (2017). Urban spatial structure, employment subcenters, and freight travel. Journal of Transport Geography, 60, 267-276.

COHEN, B. (2006). Urbanization in developing countries: Current trends, future projections, and key challenges for sustainability. Technology in Society, 28, 63-80.

CONTE, C. H., FRESCA, T. M. (2011). Cidades Médias Percursos Conceituais e Realidade - Exemplo Foz Do Iguaçu. Revista Geografar, 6(1), 192-211.

DIAS, P., ARAÚJO, M. (2013). Notas sobre Cidades Médias: Uma Proposta para a Bahia. Geo UERJ, 1, 285-311.

ESPINDOLA, G. M., COSTA CARNEIRO, E. L. N., FAÇANHA A. C. (2017). Four decades of urban sprawl and population growth in Teresina, Brazil. Applied Geography, 79, 73-83.

FRANÇA, I., SOARES, B. (2014). Centralidade e Cidades Médias: O Setor de Sáude em Montes Claros. Boletim Goiano de Geografia, 34(1), 1-15.

GAO, B., HUANG, Q., HE, C., SUN, Z., ZHANG, D. (2016). How does sprawl differ across cities in China? A multi-scale investigation using nighttime light and census data. Landscape and Urban Planning, 148, 89-98. 
GONZÁLEZ, C. M., GÓMEZ, C. D., ROJAS, N. Y., ACEVEDO, H., ARISTIZÁBAL, B. H. (2017). Relative impact of on-road vehicular and point-source industrial emissions of air pollutants in a medium-sized Andean city. Atmospheric Environment, 152, 279-289.

GULDBRAND, S., JOHANSSON, L., WESTBLOM, L. (2015). Estimating freight deliveries in urban environments - An application to Frihamnen. Master of Science Thesis in the Supply Chain Management master's Programme. Gothenburg, Sweden: Chalmers University of Technology.

GUTIÉRREZ-GALLEGO, J., RUIZ-LABRADOR, E., JARAÍZ-CABANILLAS, F., SU JEONG, J. (2015). Travel prediction methodology in medium-sized cities with GIS-T: Maximum to minimum cost disaggregation. Cuadernos Geográficos, 54, 172-195.

HOLGUÍN-VERAS, J., LEAL, J., SERUYA, B. (2017). Urban freight policymaking - The role of qualitative and quantitative research. Transport Policy, 56, 75-85.

INSTITUTO BRASILEIRO DE GEOGRAFIA E ESTATÍSTICA. (2016). Arranjos Populacionais e Concentrações Urbanas do Brasil. Rio de Janeiro.

KIBA-JANIAK, M. (2017). Urban freight transport in city strategic planning. Research in Transportation Business \& Management, 24, 4-16.

KIN, B; VERLINDE, S., MACHARISA, C. (2017). Sustainable urban freight transport in megacities in emerging markets. Sustainable Cities and Society, 32, 31-41.

KARAGIANNAKIDIS, D., SDOUKOPOULOS, A., GAVANAS, N., ITSIAVA-LATINOPOULOU, M. (2014). Sustainable urban mobility indicators for medium-sized cities: The case of Serres, Greece. In Conference on Sustainable Urban Mobility, Volos, Greece,.

KRAMAR, U., CVAHTE, T., STERNAD, M., TOPOLŠEK, D. (2015). Strategic mobility plan for a small and medium cities: Case of Celje. Spatium, 33, 47-54.

LINDHOLM, M.; BEHRENDS, S. (2012). Challenges in urban freight transport planning - a review in the Baltic Sea Region. Journal of Transport Geography, 22, 129.

MONTGOMERY, D. C., RUNGER, G. C. (2012). Estatística Aplicada e Probabilidade para Engenheiros (5. ed.). Rio de Janeiro: Editora LTC.

OLIVEIRA, L. K., MATOS, B. A., DABLANC, L., RIBEIRO, K., ISA, S. S. (2018a). Distribuição urbana de mercadorias e planos de mobilidade de carga: oportunidades para municípios brasileiros (1. ed.). Brasilia: Banco Interamericano de Desenvolvimento.

OLIVEIRA, L., BARRAZA, B., BERTOCINI, B., ISLER, C., PIRES, D., MADALON, E., LIMA, VIEIRA, J., MEIRA, L., BRACARENSE, L., BANDEIRA, R., OLIVEIRA, R., FERREIRA, S. (2018b). An Overview of Problems and Solutions for Urban Freight Transport in Brazilian Cities. Sustainability, 10, 1233-1247.

MUÑUZURI, J., LARRAÑETA, J., ONIEVA, L., CORTÉS, P. (2005). Solutions applicable by local administrations for urban logistics improvement. Cities, 22, 15-28.

POJANI, D., DOMINIC STEAD, D. (2015). Sustainable Urban Transport in the Developing World: Beyond Megacities. Sustainability, 7, 7784-7805.

PORTUGAL, L. DE S., MORGADO, A. V., LIMA JUNIOR, O. (2011). Location of cargo terminals in metropolitan areas of developing countries: the Brazilian case. Journal of Transport Geography, 19(4), 900-910.

QUAK, H.; KOSTER, M. (2009). Delivering Goods in Urban Areas: How to Deal with Urban Policy Restrictions and the Environment. Transportation Science, 43, 211-227.

RICIERI, M., FONTENELE, H., SILVA JUNIOR, C. A. (2017). Percepção de Cidadãos de uma Cidade de Médio Porte em Relação ao Uso da Bicicleta como Modo de Transporte. Revista Eletrônica de Engenharia Civil, 13, 283-296.

RØDSETH, K. (2017). Productivity growth in urban freight transport: An index number approach. Transport Policy, 56, 86-95.

SALAS-OLMEDO, M. H., NOGUÉS, S. (2012). Analysis of commuting needs using graph theory and census data: A comparison between two medium-sized cities in the UK. Applied Geography, 35, 132-141. 
SANTOS, C. (2009). A formação e produção do espaço urbano: discussões preliminares acerca da importância das cidades médias para o crescimento da rede urbana brasileira. Revista Brasileira de Gestão e Desenvolvimento Regional, 5, 177-190.

SATHLER, D., AMORIM FILHO, O., VARAJÃO, G. (2015). Cidades Médias: bases teóricas e estudos aplicados à Diamantina (1. ed.). Belo Horizonte: Fino Traço.

SCHLESINGER, J., DRESCHER, A., SHACKLETON, C. M. (2015). Socio-spatial dynamics in the use of wild natural resources: Evidence from six rapidly growing medium-sized cities in Africa. Applied Geography, 56, 107-115.

SIEGEL, S., CASTELLAN JR., N. J. (2006). Estatística não-paramétrica para ciências do comportamento. (2. ed.). Porto Alegre: Artmed.

SWIATEK, D., POKORNY, M. S., TATTO, J. A., MELO, V. A. Z. C., DIAS, E. M. (2014). Traffic management solutions in large cities - the integrated centre of urban mobility (CIMU) in São Paulo. In Proceedings of the 18th International Conference on Systems. Santorini Island, Greece. Latest Trends on System, v II.

VAN LIER, T., MEERS, D., BULDEO RAI, H., MACHARIS, C. (2016). Making Urban Freight Transport More Sustainable In A Medium Sized City: The Case Of Mechelen. In European Transport Conference, Vrije Universiteit Brussel, Research group MOBI.

VASCONCELLOS, E. A. (2005). Transport metabolism, social diversity and equity: The case of São Paulo, Brazil. Journal of Transport Geography, 13, 329-339.

\section{Editor: Fábio Duarte}

Recebido: Nov. 04, 2018

Aprovado: Jul. 24, 2019 